\title{
Development of assistive technology for the visually impaired: use of the male condom
}

\author{
DESENVOLVIMENTO DE TECNOLOGIA ASSISTIVA PARA O DEFICIENTE VISUAL: \\ UTILIZAÇÃO DO PRESERVATIVO MASCULINO
}

\section{DESARROLLO DE TECNOLOGÍA DE APOYO AL DEFICIENTE VISUAL: UTILIZACIÓN DEL PRESERVATIVO MASCULINO}

\section{Giselly Oseni Laurentino Barbosa ${ }^{1}$, Luana Duarte Wanderley², Cristiana Brasil de Almeida Rebouças $^{3}$, Paula Marciana Pinheiro de Oliveira ${ }^{4}$, Lorita Marlena Freitag Pagliuca ${ }^{5}$}

\begin{abstract}
The objectives were to develop and evaluate an assistive technology for the use of the male condom by visually impaired men. It was a technology development study with the participation of seven subjects. Three workshops were performed between April and May of 2010; they were all filmed and the statements of the participants were transcribed and analyzed by content. Three categories were established: Sexuality of the visually impaired; Utilization of the text, For avoiding STDs, condoms we will use, divided in two subcategories, Concept discussion and Text evaluation; and Construction of a simple penile prosthesis. The knowledge transmitted related to STD, the utilization of the condom on the penile prosthesis made by the subjects themselves, and the interaction during the workshops were effective factors for the study. In the context of sexual health, the necessity of developing works involving the visually impaired was noted, addressing sexually transmitted diseases and focusing on the use of the condom by this population.
\end{abstract}

\section{DESCRIPTORS}

Visually impaired persons

Sexually transmitted diseases

Self-help devices

Nursing care

\section{RESUMO}

Os objetivos foram desenvolver e avaliar uma tecnologia assistiva para a utilização do preservativo masculino por homens deficientes visuais. Estudo de desenvolvimento de tecnologia com a participação de sete sujeitos. Realizaram-se três oficinas entre abril e maio de 2010, todas filmadas, e as falas dos participantes foram transcritas e analisadas por análise de conteúdo. Estabeleceram-se três categorias: Sexualidade dos deficientes visuais; Utilização do texto Para DST evitar, camisinha vamos usar, dividido nas subcategorias Discussão dos conceitos e Avaliação do texto e Construção da prótese peniana simples. O conhecimento transmitido em relação à DST, a utilização do preservativo na prótese peniana confeccionada pelos próprios sujeitos e a interação durante as oficinas foram fatores eficazes para o estudo. No contexto da saúde sexual, percebe-se a necessidade da realização de trabalhos envolvendo os deficientes visuais, abordando as doenças de transmissão sexual e enfocando o uso do preservativo por essa clientela.

\section{DESCRITORES}

Pessoas com deficiência visual

Doenças sexualmente transmissíveis

Equipamentos de autoajuda

Cuidados de Enfermagem

\section{RESUMEN}

Los objetivos fueron desarrollar y evaluar una tecnología de apoyo para la utilización del preservativo masculino por hombres con deficiencia visual. Estudio de desarrollo de tecnología con la participación de siete sujetos. Fueron organizados tres talleres entre abril y mayo del 2010, todos filmados, y los discursos de los participantes fueron transcritos y analizados mediante el análisis de contenido. Se establecieron tres categorías: Sexualidad de los deficientes visuales; utilización del texto para evitar ITS, vamos a usar condón, dividido en las sub-categorías: Discusión de los conceptos y evaluación del texto; y construcción de la prótesis de penes. El conocimiento transmitido sobre la ITS, la utilización del preservativo en la prótesis confeccionada por los propios sujetos y la interacción durante los talleres fueron factores eficaces para el estudio. En el contexto de la salud sexual, se percibe la necesidad de realizar trabajos que involucren a los deficientes visuales, discutiendo sobre las infecciones de transmisión sexual y enfocando el uso del preservativo en esa clientela.

\section{DESCRIPTORES}

Personas con daño visual

Enfermedades de transmisión sexual

Dispositivos de autoayuda

Atención de enfermería

\footnotetext{
${ }^{1}$ Nurse. Master's student in nursing, Universidade Federal do Ceará. FUNCAP grantee. Fortaleza, CE, Brazil. gisellybarbos@hotmail.com 2 Nurse. Master's student in nursing, Universidade Federal do Ceará. FUNCAP grantee. Fortaleza, CE, Brazil. Iuana dw@hotmail.com ${ }^{3}$ Nurse. Post-Doctoral student in nursing, Universidade Federal do Ceará. CNPq grantee. Fortaleza, CE, Brazil. cristianareboucas@yahoo.com.br ${ }^{4}$ Nurse. Doctoral student in nursing, Universidade Federal do Ceará. CNPq grantee. Fortaleza, CE, Brazil. paulamarciana@yahoo.com.br ${ }^{5}$ Nurse. Doctorate, Full Professor of the Nursing Department, Universidade Federal do Ceará. CNPq researcher. Fortaleza, CE, Brazil.pagliuca@ufc.br
} 


\section{INTRODUCTION}

Assistive Technology (AT) is the entire resource and service arsenal capable of providing or enhancing abilities of people with disabilities and the elderly, in order to promote independence and inclusion ${ }^{(1)}$. Translated in a simple way, it refers to any tool or technology apparatus with the purpose of developing greater independence of people with sensory or physical limitations ${ }^{(2)}$.

Blind people have access to various AT that assist them in the learning process. Among them some adapted materials stand out, such as the Audio Book, the Extensive Reading System and operational systems in microcomputers, such as Dosvox, which has high acceptance on the part of the users, both in home and school environments, and it is one of the most widely used in the country ${ }^{(3)}$.

In reason of its high incidence, the visual impairment is representative in the Brazilian population. There are approximately 148,000 visually impaired people, which justifies the importance of working with this population ${ }^{(4)}$. Promotion of quality of life, with creation of supportive environments, access to information and promotion of individual skills, as well as integral health care assistance to people with disabilities, including specific techniques to ensure actions aimed at sexual and reproductive health, comprise two of the main guidelines of the National Health Policy for People with Disabilities ${ }^{(5)}$.

In the experience of sexuality, there are inherent differences in the condition of people with visual impairments. Because vision is the primary mean for the construction of body image, in people with visual impairment, this construction occurs primarily through touch and hearing. The touch of their own body and the way other people describe it are the key sources of information for the construction of body image in visually impaired people ${ }^{(6)}$.

Given the limited sexual health assistance focused on the visually impaired, it is worth noting the possible occurrence of Sexually Transmitted Diseases (STDs) in this population. HIV/AIDS represents a significant threat to people with disabilities throughout the world, with rates comparable to or higher than the general population ${ }^{(7)}$. Note also that these individuals have a right to information on all aspects of human existence, especially on issues related to their own health, and that they require a differentiated approach.

Health education can be an alternative capable of responding to the acquisition of positive behaviors. People with visual impairment can acquire knowledge about their own health, in order to make their own decisions, exercising in this way their rights and duties to the full exercise of citizenship ${ }^{(8)}$. In general, the educational process uses vision as a learning strategy, limiting the access to information by the visually impaired. The resources available today do not cover health promotion effectively in its diverse aspects when applied to people with visual impairment, in particular, in sexual and reproductive health.

Previous research suggested the development of educational materials to meet these needs ${ }^{(9)}$. Despite this, there is a lack of research that effectively meets this demand, which makes the development of this current study relevant. The nurse, a qualified professional in the fields of teaching, research and clinical practice, must seek the development and improvement of methods and practices to identify the effective strategies capable of increasing the health potential of the population and assisting clients to promote their health.

As part of the natural process of human development, sexuality is always present. Despite this fact, the literature on sexual education of people with visual impairment is scarce ${ }^{(8)}$. Such shortages motivated the approach to this topic in people with visual impairment, and was associated with an experience with a visually impaired mother in a previous study. Therefore, this study aimed to develop and evaluate AT focused on visually impaired men, about use of the male condom.

\section{METHOD}

This was a study about the development of assistive technology in sexual health. There were three workshops with seven visually impaired male subjects, 18 years of age or older, during the period of April to May of 2010, on days scheduled according to the availability of subjects. The workshops took place in the Communication Laboratory of the Nursing Department of the Federal University of Ceará (UFC).

The subjects were contacted through the database of the Person with Disabilities Project: investigation of nursing care, which develops several studies with this population. To determine the sample size, convenience sampling $^{(10)}$ was used, considering the type of workshop.

A text with rhyming verses was developed addressing the major STDs, family planning and condom use. This technological resource, constructed for the first workshop, was derived from the data available on the website of the Ministry of Health ${ }^{(11)}$.

For the second workshop, under the guidance of the facilitator, each participant created a prosthetic male 
genitalia with the use of modeling clay. Initially, three boxes of modeling clay were distributed to each man, who followed instructions on how to fabricate the prosthesis.

In the third workshop, the participants used the penile prosthesis for placing the condom. Initially, the instructions on the Ministry of Health website for this purpose were read entirely ${ }^{(11)}$. After that, condoms were handled, and subsequently, the prostheses. The instructions were reread for the performance of each step.

The study evaluation occurred procedurally in the course of the three workshops. First, the participants evaluated the rhyming text, later the penile prosthesis, and finally the appropriateness of the use of condoms on the prosthesis.

All workshops were videotaped and the statements were transcribed and qualitatively analyzed by the method of content analysis, a set of techniques of communication analysis, not with the aim of studying the language, but rather for the determination of the conditions of production of texts that are its object ${ }^{(12)}$. For the organization of the results, the subjects were identified by the abbreviation $\mathrm{VI}$, of Visually Impaired, and ordered 1 to 7.

As required, the project was approved by the Ethics Committee in Research of the UFC, under protocol $\mathrm{n}$ ㅇ $312 / 09$. The ethical principles were respected and the subjects signed the Terms of Free and Informed Consent, after it was read and explained in the presence of seeing witnesses.

\section{RESULTS}

Seven men, aged between 23 and 59 years old, and with visual impairment participated in the study. Two reported low vision and five reported total blindness. Regarding education, two attended the mode of youth and adult education in a special school, three completed high school, and had incomplete high school, and the other had an incomplete university degree. Concerning marital status, three were married, two were in a stable relationship, and the other two were single.

In the first workshop the participation of seven subjects was obtained. A text with rhyming verses named, For avoiding STDs, condoms we will use, was used addressing the major STDs, citing family planning, directed the use of condoms. This text is available on the website www.labcomsaude.ufc.br. The sexuality of the visually impaired was discussed and, after that, there was the reading of the text, followed by reading paused for discussions for clarification of information. At the end, participants performed an evaluation according to language, content and the form of approach of the rhymed text in the formal group, upon request of the facilitator for those aspects. This workshop had the duration of one hour and thirty minutes.

In the second workshop, five men participated, because two dropped out and, when contacted, claimed personal reasons to justify the withdrawal. Together with the facilitator, prostheses were made by the subjects of the male genitalia, called simple penile prosthesis, constructed with modeling clay. All of the participants were able to fabricate their prostheses. After that time, they were passed from right to left so that each man could know all the prostheses. In this way, interaction was promoted between them. At the completion of the practical activity, there was a group assessment about the material produced. This second meeting lasted for about forty minutes. At the end, the prostheses were identified with the author's name and stored in an appropriate place.

In the third workshop, five men remained. The prostheses constructed in the previous meeting were used for orientation of the correct use of the condom. The instructions on the website of the Ministry of Health were read ${ }^{(11)}$ and, after adjustment for the population was crafted, the subjects placed the condom. In a similar way, the condom was removed according to the instructions. The workshop lasted thirty minutes.

For data analysis, the following categories were established: (1) Sexuality of the visually impaired and ${ }^{(2)}$ Use of the text For avoiding STDs, condoms we will use divided in two subcategories: (2.1) Concept discussion and (2.2) Text evaluation and ${ }^{(3)}$ Construction of simple penile prosthesis.

\section{CATEGORY 1: Sexuality of the visually impaired}

There are people who think that blind people do not date (...) The deficient, the blind, also date (VI 7).

The visual impaired are like other people. There are the married ones that also date outside of their marriages. There are many people that think that the visually impaired cannot do this type of thing (VI 3).

It is interesting to do a work of divulgation, first at the radio, talking about sexuality of blind people. People think that the blind cannot date, that they cannot have anything (VI 2).

It is also noted that the visually impaired knew the social imagination and believed that disclosure could demystify the concepts about their sexuality. They stated they were sexually capable, including the insinuated issue of cheating. Furthermore, they reported interest in the propagation of information by means of this work

\section{CATEGORY 2: Use of the text For avoiding STDs, condoms we will use}

\section{Subcategory 2.1: Concept discussion}

After reading the full text, another reading was done with pauses, when the discussions occurred. During the reading, the subjects expressed themselves:

What is the relation between prostatic cancer and HPV? And about syphilis? I know that there are many blind people because of the occurrence of syphilis... (VI 5).
Development of assistive technology for the visually impaired: use of the male condom Barbosa GOL, Wanderley LD, Rebouças CBA, Oliveira PMP, Pagliuca LMF 
It is very important to know. I am not seeing, but I am feeling (...) If it appears, I have to treat it! [syphilis wound] Can gonorrhea be caught from a seat? (VI 7).

I know someone who had HIV and when went out, he pierced his finger and put the blood in cups with drinks and gave to several people (...) (VI 7).

The person informed about the symptoms of the disease is easier to know and recognize the disease (...) (VI 3).

Throughout the reports, information and questions inherent to the various aspects of STDs were observed. During the discussions, the doubts were clarified as well as conceptions that were incorrect.

\section{Subcategory 2.2: Evaluation of the text For avoiding STDs, condoms we will use}

As proposed, the study participants evaluated the educational text. The subjects verbalized their opinions about the language used, the content presented and the manner of approach. The statements identified were:

We know that there are many diseases, much information

(...) For me, the text was very tiring and we got lost (...) The idea of the rhymed text is very good, but for having to much information(...) it could be more divided(VI 2).

The text is well explained and the rhymes stimulate the people to read (VI 5).

I liked the presentation of the text in the two ways you did. Because of the use of rhymes, and for presented the text directly, without any interruption and then the second time giving the possibility of people discussing the text. It would be tiring if you had only discussed and explained the text (...) But they let us discuss. One thing is just to hear people talking, another is I go there to talk with those people. For me, it was excellent (VI 3).

For most, the text was shown to be adequate and of approach was acceptable. However, one participant found it tiring due to the amount of information.

\section{CATEGORY 3: Construction of simple penile prosthesis.}

In this category, the comments were:

The more you pinch it, it gets worse [modeling clay] (VI 6).

For me it was very interesting because I have a hard time with anything handmade (...) I do not know if it is my addiction to informatics, but (...) (VI 4).

The learning, the technique for doing this is interesting (...) It is useful to practice these things, especially for blind people. (VI 7).

After blindness, everything I do with my hands and my mind has value (...) What I do today, I did not do when I had sight (VI 7).

To see we need our eyes, but to visualize we do not need them. We see with the mind, with the heart... (VI 6).
As is apparent from the reports, physical and emotional feelings became important for the experience. The participants emphasized the relevance of the activity to be used with individuals lacking vision. The active participation of the visually impaired was evident in the moments in which they were devoted to modeling the penile prosthesis and commented on their results with others.

\section{DISCUSSION}

The first category emphasized how society perceives the sexuality of the visually impaired and how they themselves verbalize it. According to the literature, sexuality is a dimension of the human being understood as a mediator of social relations, able to condense the exercise of one's autonomy, being more focused on the personal development and interaction with others. Generally, the sexual practices differ within each society and change according the reference of the different social segments that compose them. Thus, sexuality in its manifestation and expressions has different meanings, in line with the existing values in a sociocultural stratum ${ }^{(13)}$.

When addressing the sexuality of the person with disabilities, this human dimension starts to be seen as more complex. One of the major difficulties for the discussion of sexuality in this population is due to the almost total lack of experience reports about the subject. This absence may be related to prejudice and discrimination still existent from which such people could not exercise their sexuality completely ${ }^{(14)}$.

Based on a historical-cultural perspective, it is transmitted the idea that the visually impaired are incapable, awkward, insecure. Such ideas can influence them to be helpless, dependent, asexual and unattractive, making it difficult to live their sexuality in a healthy way and this may cause disastrous consequences ${ }^{(15)}$. However, a selfaffirmation of sexuality among the visually impaired population of the study was observed. They had knowledge of the social imagery about them and an interest in changing points towards to an awareness of themselves and of the dimensions that are their right.

Considering that people with disabilities are targets of social stigma, reflected in terms of their sexuality, if STD/ AIDS pose a risk to people with disabilities, they become much larger for disabled people ${ }^{(16)}$. Thus, working with sexual health must occur in order to meet the deficits of this population. A study suggested the development of educational materials to meet these needs ${ }^{(9)}$. However, it is observed the lack of research to effectively meet this demand, which makes this current study relevant.

In the second category the use of rhyming text was presented as the approach for the STD and it addressed the sexually transmitted diseases in terms of their characteristics, 
symptoms and treatments. The first subcategory involved the discussions promoted during the reading of the rhyme. As noticed, the doubts related to the forms of contamination, complications and treatment of diseases, as well as gender issues and the relevance of information about STDs were aspects identified in the verbalizations of subjects.

Through the reports, a mix of information and questions were found. In the approach of Condyloma Acuminata caused by Human Papillomavirus (HPV), doubts about the types of correlated cancers were mentioned. This STD may be related to cervical, penile and anal cancer ${ }^{(11)}$. One of the subjects questioned the existence of a relationship between HPV and prostate cancer. This relationship was negated during the discussions, corroborating a study that affirmed the inexistence of significant evidence that this virus was actively involved in the carcinogenesis of prostate cells ${ }^{(17)}$.

Regarding the forms of HIV infection, it was known that it occured through unprotected sexual contact with a HIV-positive person; direct contact with infected blood; transfusions of blood and/or blood products; accidents with biological materials that generate direct contact with mucous membranes, injured skin or wound, and deep tissues of the body that give access to the bloodstream; and the HIV-infected mother to her child during pregnancy, childbirth or breastfeeding ${ }^{(11)}$.

In one of the verbalizations a form of nonexistent HIV infection was presented. Given this, the need for blood contact with the contaminated blood of another individual to have contamination was reinforced, and the impossibility of this contact through droplets of blood in beverages was clarified. To have the possibility of oral transmission, it would be necessary to have a serious injury to gums and bleeding in the mouth ${ }^{(18)}$.

A study with blind adolescents revealed unawareness and misinformation about the forms of STD transmission, which was due to, among other factors, the lack of materials adapted for the acquisition of information ${ }^{(8)}$. Thus, it becomes relevant to each and every action in regard to guidelines about STDs, especially with the disabled clientele, in the present study focused on the visually impaired. A shortage of care actions within basic needs and according to what is guaranteed by law was verified.

As for the condom, it is thought that the intervention of the health teams should emphasize its constant use in all sexual relations, with a larger number of incentive campaigns to increase the use of male condoms as well as female ${ }^{(19)}$. In reference to visually impaired clients, those actions should also be strengthened. By directing our gaze to the gender issue, women with disabilities are more likely to have lower levels of education, more susceptible to face unemployment or underemployment and to confront unstable relationships, and are less likely to marry ${ }^{(7)}$. The problems faced by them may be aggravated considering that, besides being women, they have a limitation and are seen by society as inferior, which may involve greater submission to men.

It is believed that the awareness about the risks must be worked on not only with women, because they are more vulnerable, but also with men because they may also become infected in unprotected sex. The knowledge is considered essential for the acquisition of this self-perception. In one of the statements, one participant cited the need for information about the characteristics of diseases and their possible identification. In the second subcategory the statements of the subjects in the valuation of the rhymed text For avoiding STDs, condoms we will use were identified. Consistent with a previous study, that adopted pamphlet literature in the context of breastfeeding for blind people, a rhyme inserted in the verses that makes the line interesting, since it is a strategy to be used by nurses to consolidate effective interventions ${ }^{(20)}$. According to the results, the language was easy to understand, the form of discussion was wise and rhyming text encouraged attention to the reading.

For some people, however, certain strategies may not be the best manner to assimilate understanding. A study participant considered the text tiring due to the amount of information it contained, but agreed with the others on the use of rhymes. The STD approach regarding manifestation, complications and treatment of the diseases presents a range of information that require efforts to make its transmission attractive.

Regardless of the communication capacity of the patient, the nurse needs to work hard to know his repertoire and express herself in an understandable language ${ }^{(21)}$. In the perspective of the blind people, the technological resources used presented a simple and easy to understand language, in a way that the approach to the text was enjoyable.

According to the literature, besides the use of means that involves speech and hearing, it is necessary to involve touch, another sense relevant to the performance of certain activities by the visually impaired person. Aside from the resource of hearing, the amount of information transmitted through touch, including reading, is extraordinarily immense and complex and is hardly evaluated in an appropriate manner by sighted individuals ${ }^{(6)}$.

The visually impaired person should be exposed to different situations and challenges, with incentives equal or superior to those used with individuals endowed with normal vision, considering the restriction of senses, because although the vision is essential for the acquisition of information, experiences and experiments, it is not the only way ${ }^{(15)}$. In this study, we explored manual work by the subjects by means of the molding of a penile prosthesis for the practice of placing the condom..

The third category described statements about the molding of the simple penile prosthesis. As mentioned,
Development of assistive technology for the visually impaired: use of the male condom Barbosa GOL, Wanderley LD, Rebouças CBA, Oliveira PMP, Pagliuca LMF 
the material used was modeling clay and, despite reports on the lack of manual skills, all participants produced the proposed object. For the construction of the prosthesis of male genitalia, the ease of access and low cost of the product was considered, which can allow greater scope for its use. It is believed that the effective participation in the construction of the prosthesis prior to the later placement of the condom promoted greater interest to further explore the tactile feature.

During the molding process, subjects reported difficulties and opined about how to fabricate the prosthesis. Moreover, the very conception of the visually impaired about their visual impairment was explored. For the subjects, the lack of vision does not prevent the execution of different tasks. There were reports of overcoming after the loss of vision, with the appreciation of activities not considered relevant prior to the blindness. Despite the perceived difficulty reported by one of the men, the prosthesis was completed, making it possible to practice placing the condom.

Regarding the apprehension of concepts, despite the sensory impairment, the visually impaired perceive, absorb and remember content in several ways. There is a selective perception and interpretation of content that involves the process of communication and learning ${ }^{(22)}$.

For the construction of the penile prosthesis, the instructions were narrated while the participants performed the activity. The understanding as to how to construct was satisfactory, because all participants constructed the prosthesis. Therefore, in the context of the visually impaired, the creation of technologies is relevant to enable the correct use of condoms, through means of awareness of the damage and injuries caused by STDs and the correct technique of placing the product.

Considering the materials used in this study, in search of contextualizing STDs, the use of male condoms for safe sex for visually impaired men is a proposal for social inclusion. In one of the statements, it was possible to understand the perception of one of the subjects in relation to the skill with condoms. According to the report, this practice is valid, particularly for people with visual impairments.

\section{CONCLUSION}

The AT developed used here was an educational text for the approach of STDs, the molding of a penile prosthesis, and training of male condom placement on this prosthesis. These steps were applied along with the study subjects in educational workshops. It is concluded that the development and evaluation of the AT occurred effectively.

In the perception of the participants, the educational text promoted learning. Due to the amount of information, the text was also considered tiring, although softened by the rhyme.

The modeling clay used for the molding of the penile prosthesis, made by all participants, was perceived as adequate. The involvement of the study subjects in the work process, to incentivize them to construct the penile prosthesis, proved to be a satisfactory strategy. Resources like this can be developed in order to promote learning and interaction during the activities. The lack of vision was not an impediment in the construction of the material with modeling clay and stimulated the tactile activity.

In the training for placement of the condom on the prosthesis, there was agreement as to its effectiveness. The critical thinking related to the practice of safe sex was indicated as an aspect present in the discussions, thus, it is believed studies such as this are needed to meet a health necessity considered common, but rarely addressed to visually impaired people: - sexual heath.

Therefore, performing actions to implement sexual health education to visually impaired population is considered necessary because it can promote greater inclusion and reduce prejudice. The production of works involving people with disabilities is emphasized, especially the visually impaired, in the context of sexual health. Sexually transmitted disease must be prioritized along with a focus on condom use. Through information, people may become more capable in pursuit of their rights and ensuring their health, one of the most important assets of the human condition.

As a mediator of the relationships of the visually impaired with the health service, the nurse must strive for effectiveness of care. Health education, even with adapted resources, is a means by which this professional can ensure quality health care and, by extension, a more inclusive and healthier disabled population.

The study showed positive results, but the small sample set a limit to be exceeded on other occasions. It should also be considered educational experiences that will bring sighted and visually impaired people closer. In future perspective, the objective is the dissemination of the AT for a representative number of visually impaired people, as the lack of publications on the subject is evident.

\section{REFERENCES}

1. Bersch RCR. Introdução à tecnologia assistiva [Internet]. Porto Alegre: CEDI; 2008 [citado 2011 jul. 29]. Disponível em: http://proeja.com/portal/images/semana-quimica/2011-10-19/tec-assistiva.pdf

2. Hogetop L, Santarosa LC. Tecnologias assistivas: viabilizando a acessibilidade ao potencial individual. Inf Educ Teor Prat [Internet]. 2002 [citado 2011 jul. 15];5(2). Disponível em: http:// seer.ufrgs.br/InfEducTeoriaPratica/article/view/5277/3487 
3. Cerqueira JB, Ferreira EMB. Recursos didáticos na educação especial. Rev Benjamim Constant [Internet]. 2000 [citado 2011 jul. 22];6(15):24-8. Disponível em: http://www.ibc.gov. $\mathrm{br} /$ ?catid $=4 \&$ itemid $=57$

4. Instituto Brasileiro de Geografia e Estatística (IBGE). Censo demográfico 2000: características gerais da população [Internet]. Rio de Janeiro; 2010 [citado 2010 jan. 13]. Disponível em: http://www.ibge.gov.br/home/estatistica/populacao/ censo2000/populacao/censo2000_populacao.pdf

5. Brasil. Ministério da Saúde; Secretaria de Atenção à Saúde. Política Nacional de Saúde da Pessoa Portadora de Deficiência [Internet]. Brasília; 2008 [citado 2011 jul. 22]. Disponível em: http://bvsms.saude.gov.br/bvs/publicacoes/politica_nacional_saude_pessoa_deficiencia.pdf

6. França DNO, Azevedo EES. Imagem corporal e sexualidade de adolescentes com cegueira, alunos de uma escola pública especial em Feira de Santana, Bahia. Rev Ciênc Med Biol. 2003;2(2):176-84.

7. Groce N. Levantamento Mundial sobre HIV/Aids e Deficiências [Internet]. New Haven: Global Health Division, Yale School of Public Health; 2004 [citado 2009 out. 30]. Disponível em: http://globalsurvey.med.yale.edu/capturing_hidden_voices_portuguese.pdf

8. Moura GR, Pedro ENR. Visually impaired teenagers: perceptions on sexuality. Rev Latino Am Enferm. 2006;14(2):220-6.

9. López Jaime P, Santos Ortíz MC, Dávila Torres RR, Torres L, Díaz L. Knowledge about sexuality and sex behavior in university students with visual impairment: need of educational materials. P R Health Sci J. 2001;20(3):269-75.

10. LoBiondo-Wood G, Haber J. Pesquisa em enfermagem: métodos, avaliação, crítica e utilização. Rio de Janeiro: Guanabara Koogan; 2001.

11. Brasil. Ministério da Saúde, Departamento de DST, Aids e Hepatites Virais. Portal sobre aids, doenças sexualmente transmissíveis e hepatites virais [Internet]. Brasília; 2010 [citado 2010 fev. 8]. Disponível em: http://www.aids.gov.br/pagina/dst-1

12. Bardin L. Análise de conteúdo. Lisboa: Edições 70; 2008.

13. Brandão ER, Heilborn ML. Sexualidade e gravidez na adolescência entre jovens de camadas médias do Rio de Janeiro, Brasil. Cad Saúde Pública. 2006;22(7):1421-30.
14. Bastos OM, Deslandes SF. Sexualidade e o adolescente com deficiência mental: uma revisão bibliográfica. Ciênc Saúde Coletiva. 2005;10(2):389-97.

15. Bruns MAT. Deficiência visual e educação sexual: a trajetória dos preconceitos - ontem e hoje. Rev Benjamim Constant [Internet]. 2000 [citado 2010 nov. 23]; 17(6):24-30. Disponível em: http://www.ibc.gov.br/?itemid=103

16. Sousa FS, Baptista RS, Coura AS, França EG, Pagliuca LMF, França ISX. Sexuality of disabled people and vulnerability to aids: sistematic literature review. Online Braz J Nurs [Internet]. 2009 [cited $2010 \mathrm{Apr}$ 17];8(3). Available from: http://www.objnursing.uff.br/index.php/nursing/article/ view/j.1676-4285.2009.2566/html_51

17. Machado MT, Kappáz GT, Debert I, Goldenstein PT, Aldrighi APS, Simardi LH, et al. HPV e câncer de próstata: análise crítica do envolvimento na carcinogênese da célula prostática. Arq Med. 2001;25(2):18-23.

18. Brasil. Ministério da Saúde. Programa Nacional de DST e AIDS. Aids: assim pega, assim não pega! [Internet]. Brasília; 2010 [citado 2010 jun. 1]. Disponível em: http:// bvsms.saude.gov.br/html/pt/dicas/153assim_pega_assim_nao_pega.html

19. Taquette SR, Andrade RB, Vilhena MM, Paula MC. A relação entre as características sociais e comportamentais da adolescente e as doenças sexualmente transmissíveis. Rev Assoc Med Bras. 2005;51(3):148-52.

20. Oliveira PMP, Rebouças CBA, Pagliuca LMF. Construção de uma tecnologia assistiva para validação entre cegos: enfoque na amamentação. Rev Bras Enferm. 2009;62(6):837-43.

21. Costa KNFM, Pagliuca LMF, Almeida PC, Cardoso MVLML, Rebouças CBA. Aspectos da comunicação verbal entre enfermeiros e pessoas com deficiência visual. Rev RENE. 2009;10(2):29-36.

22. Bezerra CP, Pagliuca LMF. The experience of sexuality by visually impaired adolescents. Rev Esc Enferm USP [Internet]. 2010 [cited 2011 July 22];44(3):578-83. Available from: http://www.scielo.br/pdf/reeusp/v44n3/en_05.pdf

\section{Akcnowlwdgments}

Study developed with a grant from CNPq.
Correspondence addressed to: Giselly Oseni Laurentino Barbosa 251 Dr. Suliano St. - Jóquei Clube CEP 60510-220 - Fortaleza, CE, Brazil 